\title{
Study of association between genetic polymorphisms of phospholipase A2 enzymes and Alzheimer's disease
}

\author{
Quirino Cordeiro' ${ }^{1}$ Ricardo Noguti', \\ Cássio M.C. Bottino², Homero Vallada
}

\begin{abstract}
Several genes have been related to late-onset Alzheimer's disease (LOAD). Phospholipases A2 (PLA2) influence the processing and secretion of the amyloid precursor protein, which gives rise to the beta-amyloid peptide, the major component of the amyloid plaque in AD. Hence, in the present study, polymorphisms of three genes encoding PLA2 enzymes group (cytosolic PLA2: Banl cPLA2 polymorphism; calcium-independent PLA2: Avrll iPLA2 polymorphism; PAFAH: Val279Phe PAFAH polymorphism) were analysed in a case-control sample using 58 patients with LOAD and 107 matched healthy controls. There was a genotypic association between the Banl cPLA2 polymorphism and $\operatorname{LOAD}\left(\chi^{2}=6.25,2 \mathrm{df}\right.$, $p=0.04$ ), however there was no allelic association. There were no associations between Avrll iPLA2 and Val279Phe PAFAH polymorphisms and LOAD. These data suggest that the Banl CPLA2 polymorphism may play a role in the susceptibility for LOAD in our Brazilian sample. Key words: PLA2, dementia, gene, genetics, LOAD.
\end{abstract}

Associação entre polimorfismos das enzimas fosfolipases A2 e doença de Alzheimer

\section{RESUMO}

Vários genes têm sido investigados como fatores de risco para o desenvolvimento da doença de Alzheimer (DA) de início tardio. As fosfolipases A2 (PLA2) influenciam o processamento e secreção da proteína precursora do amilóide, que dá origem ao peptídeo meta-amilóide, o principal componente da placa amilóide na DA. Assim, no presente estudo, foram analisados três polimorfismos genéticos que codificam enzimas do grupo das PLA2 (PLA2 citosólica: polimorfismo Banl CPLA2; PLA2 cálcio-independente: polimorfismo Avrll iPLA2; PAFAH: polimorfismo Val279Phe PAFAH) em 58 pacientes com DA de início tardio e 107 controles saudáveis pareados. Houve associação genotípica entre o polimorfismo Banl cPLA2 e DA de início tardio $\left(\chi^{2}=6,25,2 d f, p=0,04\right)$; no entanto não foi observada associação alélica. Não houve associação entre os polimorfismos Avrll iPLA2 e Val279Phe PAFAH com a doença. Tais dados sugerem que o polimorfismo Banl cPLA2 pode estar envolvido como fator de susceptibilidade para DA de início tardio em nossa amostra brasileira. Palavras-chave: PLA2, demência, gene, genética, Alzheimer de início tardio.

Correspondence Quirino Cordeiro Rua Cônego Eugênio Leite 594 / 174 05414-000 São Paulo SP - Brasil E-mail: qcordeiro@yahoo.com

Received 4 June 2009

Received in final form 21 September 2009 Accepted 5 October 2009 ic and environmental factors. It is accepted that Apolipoprotein E (ApoE) allele 4 is a major genetic risk factor for $\mathrm{LOAD}^{2-4}$. However ApoE allele 4 may only account for about $50 \%$ of the susceptibility for LOAD which suggests that there may be additional genetic risk factors for $\mathrm{LOAD}^{5}$.

Institute of Psychiatry, University of São Paulo Medical School, São Paulo SP, Brazil: 'Program of Genetics and Pharmacogenetics (PROGENE); ${ }^{2}$ Old Age Research Group (PROTER). 
Several candidate genetic polymorphisms related to systems supposedly involved with AD pathophysiology have been implicated in the susceptibility for LOAD, but none has been consistently replicated ${ }^{6,7}$. Brain phospholipids are interesting sites for the interaction between genes and environment because enzymes and other proteins that regulate phospholipid metabolism are clearly genetically determined ${ }^{8}$.

Phospholipases A2 (PLA2) are enzymes involved in several physiological processes, such as phospholipids metabolism, remodeling of cell membranes, and intracellular signaling. PLA2 has been related to the cleavage of membrane phosphatidylcoline and releasing of choline, the principal precursor for the synthesis of acethylcoline. Problematic functioning of the neuronal unsaturatted fatty acid metabolism by PLA2 may provoke alterations in the neuronal membrane structure and fluidity, modify intracellular signaling and neurotransmission ${ }^{9}$. Investigations with 31P-spectroscopy studies performed with AD patients have evidenced decreased membrane phospholipids turnover in temporoparietal cerebral areas ${ }^{10}$, being these data in accordance with the findings of decreased PLA2 metabolites in the parietal cortex of postmortem AD brains ${ }^{11}$. Brain and platelet PLA2 activity reduced has also been described in patients with $\mathrm{AD}^{12,13}$. Decreased activity of PLA2 in the frontal and parietal cortex was associated to earlier onset of dementia, earlier age at death, and higher counts of neurofibrillary tangles and senile plaques $^{13}$. In vitro study has shown that PLA2 are involved in the regulation of amyloid precursor protein ${ }^{14}$. Thus findings from experimental and clinical investigations have supported the hypothesis that alterations in membrane phospholipids metabolism, related to reduced PLA2 activity, may be involved in the pathogenesis of $\mathrm{AD}^{15}$.

In face of the evidences for the involvement of the PLA2 system in the pathophysiology of LOAD, the genes encoding PLA2 enzymes could be considered as plausible candidate in the susceptibility for the disease. Thus, in the present study, we examined, in a case-control sample, polymorphisms in the genes codifying the following $\mathrm{PLA}_{2}$ isoforms: the cytosolic phospholipase A2 (cPLA2), the calcium-independent phospholipase A2 (iPLA2) and the plasma platelet-activating factor acetylhydrolase (PAFAH) ${ }^{16}$.

cPLA2, PLA2 group 4A, also known as PLA2G4A, is a large molecular weight protein, activated by calcium in the cytosol, and catalyzes the release of arachidonic acid from membrane phospholipids. cPLA2 gene ( $C P L A 2)$ is located on chromosome 1q25. The BanI cPLA2 polymorphism (A/G polymorphism: A1 versus A2 allele), located near the first intron of $c P L A 2$, will be investigated ${ }^{17}$.

iPLA2, PLA2G6, catalyze hydrolysis of the sn-2 acyl-ester bonds in phospholipids, leading to the release of arachidonic acid and other fatty acids. PLA2G6 is a calcium-in- dependent PLA2. iPLA2 gene (iPLA2) was mapped to chromosome 22q13.1 and contains 19 exons $^{18}$. The iPLA2 AvrII polymorphism will also be investigated as a possible risk factor for LOAD.

PLA2 group 7, plasma platelet-activating factor acetylhydrolase, PLA2G7, is a secreted enzyme that catalyzes the degradation of platelet-activating factor to inactive products by hydrolysis of the acetyl group at the sn-2 position, producing the biologically inactive products LYSOPAF and acetate. Stafforini et al. ${ }^{19}$ mapped the PLA2G7 gene (PAFAH) to chromosome 6p21.1-p12 and found that it contains 12 exons. Deficiency of plasma platelet-activating factor resulting from a missense mutation (Val279Phe) in exon 9 of the gene has been described.

Val279Phe PAFAH polymorphism will be investigated in the present study ${ }^{19}$.

\section{METHOD}

\section{Sample}

Fifty-eight ( $\mathrm{n}=58)$ unrelated Brazilian patients with LOAD, diagnosed according to the National Institute of Neurological and Communicative Disorders and Stroke and the Alzheimer's Disease and Related Disorders Association (NINCDS-ADRDA) Alzheimer's criteria ${ }^{20}$, were recruited from the Institute of Psychiatry of São Paulo University Medical School (31.03\% males and 68.96\% females; with mean age of 73.56 years $6.60 \mathrm{SD} \pm$ ). A total of 107 matched control subjects (31.77\% males and $68.22 \%$ females; with mean age of 72.18 years $5.03 \mathrm{SD} \pm$ ) were recruited from the general population in São Paulo. The study was approved by the Ethical Committee of São Paulo University Medical School. The patients or their relatives signed an informed consent form and venous blood samples were collected.

\section{Genotyping}

Genomic DNA samples were extracted from lymphocytes. The genetic variants studied are described below:

\section{cPLA2 - BanI polymorphic site}

PCR amplification for this dimorphic site, described by Peet et al. $(1998)^{21}$, was performed using the primers: 5'- AAGGGATATTTGTAGAGGACT-3' and 5'TAGATGATTCGATTTTATGACT-3' and the following conditions: 35 cycles with an annealing temperature of $50.5^{\circ} \mathrm{C}$. The $788 \mathrm{bp}$ product was digested with $\mathrm{BanI}$ and the alleles separated in $1 \%$ agarose gel. The A1 allele was not digested with the enzyme, and A2 allele was digested in two fragments of 452 and 336 base pairs (bp).

\section{iPLA2 - AvrII polymorphic site}

PCR amplification for this single nucleotide polymorphism (SNP) C/T that alters the restriction site of AvrII on the iPLA2 gene ${ }^{22}$, was performed using the primers: 5' GGGGTTTATTTTGCTGGGTT 3' (forward) and 5' 
CAAGGGTGAT GGGGAGATC 3'(backward). The conditions for thermal cycling were: an initial cycle $94^{\circ} \mathrm{C}$ for $5 \mathrm{~min}$ followed by $24 \mathrm{cycles}$ each of $93^{\circ} \mathrm{C}$ for $30 \mathrm{~s}, 60^{\circ} \mathrm{C}$ for $30 \mathrm{~s}$ and $72^{\circ} \mathrm{C}$ for $30 \mathrm{~s}$ and a final step of $72^{\circ} \mathrm{C}$ for $5 \mathrm{~min}$. The 380-bp products were digested with Avr II with the $\mathrm{T}$ allele uncut, and the $\mathrm{C}$ allele cut into $182 \mathrm{bp}$ and 198 bp fragments.

\section{PAFAH - Val279Phe variant}

PCR amplification for this variant, described by Stafforini et al. $(1996)^{19}$, was performed with primers sequences 5'- CTATAAATTTATATCATGCTT-3' 5'- TTTACTATTCTCTTGCTTTAC-3. The conditions for thermal cycling consisted of denaturation at $94^{\circ} \mathrm{C}$ for $5 \mathrm{~min}$ followed by 5 cycles at $94^{\circ} \mathrm{C}(1 \mathrm{~min}), 56^{\circ} \mathrm{C}(1 \mathrm{~min}), 72^{\circ} \mathrm{C}(1$ $\mathrm{mim})$ and $25 \mathrm{cycles}$ at $94^{\circ} \mathrm{C}(30 \mathrm{sec}), 52^{\circ} \mathrm{C}(30 \mathrm{sec}), 72^{\circ} \mathrm{C}$ (30 sec) before a final extension step at $72^{\circ} \mathrm{C}$ for $7 \mathrm{~min}$. The 177-bp product was digested with MaeII to yield 95 bp and $82 \mathrm{bp}$ fragments. The alleles were separated on $10 \%$ polyacrylamide gels.

\section{Statistical analysis}

Chi-squared test was performed to compare overall allele and genotype frequencies of the polymorphism between cases and controls using the statistical software EpiInfo 2000, version 1.1.2. The Hardy-Weinberg equilibrium test was performed by the HWE program.

\section{RESULTS}

\section{CPLA2}

The genotypic and allelic distribution of the dimorphic site for the restriction enzyme BanI are shown on the Table. There was a statistic significant difference in genotypic frequency between LOAD patients and control subjects $\left(\chi^{2}=6.25,2 \mathrm{df}, \mathrm{p}=0.04\right)$. However there was no allelic association $\left(\chi^{2}=2.62,1 \mathrm{df}, \mathrm{p}=0.10\right)$. There was no homozi- gosity association as well $\left(\chi^{2}=2.48,1 \mathrm{df}, \mathrm{p}=0.11, \mathrm{OR}=1.68\right.$, $0.84<\mathrm{OR}<3.37)$. Allele frequencies and genotypic distribution of the polymorphisms were in Hardy-Weinberg equilibrium (patients: $\mathrm{p}=0.06$; controls: $\mathrm{p}=0.40$ ).

\section{iPLA2}

The genotypic and allelic distribution of the dimorphic site of the restriction enzyme AvrII in the iPLA2 gene are shown on the Table. There was no significant difference in genotypic $\left(\chi^{2}=3.74,2 \mathrm{df}, \mathrm{p}=0.15\right)$ and allelic $\left(\chi^{2}=1.03\right.$, $1 \mathrm{df}, \mathrm{p}=0.30)$ frequencies between LOAD patients and controls. There was no association with homozigosity $\left(\chi^{2}=2.79,1 \mathrm{df}, \mathrm{p}=0.09\right)$. Allele frequencies and genotypic distribution of the polymorphisms were in Hardy-Weinberg equilibrium (patients: $\mathrm{p}=0.10$; controls: $\mathrm{p}=0.52$ ).

\section{PAFAH}

The Phe mutation in the PAFAH occurred in a low frequency in our sample. Only one heterozygous individual was detected. The homozygous genotype (Phe/Phe) was not present in our sample. Therefore the present polymorphism is not likely to be associated with LOAD. Allele frequencies and genotypic distribution of the polymorphisms were in Hardy-Weinberg equilibrium (patients: $\mathrm{p}=0.94$; controls: $\mathrm{p}=1.00$ )

\section{DISCUSSION}

LOAD etiology is likely to be complex, involving multiple genes in addition to environmental effects and their interactions. Trying to bring light on the findings of an abnormal PLA2 activity in the AD, we examined the association of three genetic polymorphisms encoding PLA2 isoforms and LOAD. We are not aware of any previous report of an association study between these polymorphisms and LOAD to date.

Table. Distribution of genotypes and alleles of CPLA2, iPLA2 and PAFAH genes variants among patients with LOAD and healthy controls.

\begin{tabular}{lcccc}
\hline Locus & Genotypes/alleles & Patients (\%) & Controls (\%) & p value \\
\hline CPLA2 & A1/A1 & $5(8.6)$ & $26(24.2)$ & 0.043 \\
& A1/A2 & $34(58.6)$ & $49(45.7)$ & \\
A2/A2 & $19(32.7)$ & $32(29.9)$ & \\
& A1 & $44(37.9)$ & $101(47.1)$ & 0.10 \\
A2 & $72(62.0)$ & $113(52.8)$ & \\
& T/T & & & \\
& T/C & $13(22.4)$ & $25(23.3)$ & 0.15 \\
& C/C & $35(60.3)$ & $50(46.7)$ & \\
& T & $10(17.2)$ & $32(29.9)$ & \\
& C & $61(52.5)$ & $100(46.7)$ & 0.30 \\
& & $55(47.4)$ & $114(53.2)$ & \\
\hline
\end{tabular}


Regarding the BanI polymorphism there was a genotypic association with LOAD. Our findings suggest that the alelle $\mathrm{A} 1$ may be a genetic factor of protection to $\mathrm{AD}$ in order of the important difference in the distribution of the $\mathrm{A} 1$ and $\mathrm{A} 2$ alleles between patients and controls and the substantial underrepresentation of the homozygous $\mathrm{A} 1 / \mathrm{A} 1$ on $\mathrm{AD}$ group.

Functional significance of the BanI $c P L A 2$ polymorphism has been investigated. Barbosa et al. ${ }^{8}$ found that cPLA2 activity in platelets was significantly higher in schizophrenic patients with the A2A2 genotype. Therefore our results with $\mathrm{AD}$ patients were in the opposite direction of this functional study of the BanI $c P L A 2$ polymorphism. Such phenomenon may be related to ethnical population stratification. So it could be premature to assess the validity of the association of LOAD and the investigated polymorphism because it may be in tight linkage with another polymorphism which could influence the risk for the disease. If the BanI $c P L A 2$ polymorphism is tightly linked with a polymorphism of risk for LOAD, different patterns of linkage disequilibrium may exist between different ethnical samples. Thus a specific allele could be linked to the risk-conferring allele in some populations, but could be linked with the non-risk allele in others ${ }^{23,24}$.

Interestingly, $C P L A 2$ is located on chromosome 1q25, immediately adjacent to the region 1q23 where Blacker et al. ${ }^{25}$ reported suggestive linkage with LOAD. This region is also close to the gene encoding nicastrin, which binds presenilin and is required for $\gamma$-secretase activity and beta-amyloid generation ${ }^{26}$.

The restriction polymorphism by $A v r I$ in the $\mathrm{PLA}_{2}$ gene did not show allelic or genotypic association with LOAD. In addition to the obvious explanation that this polymorphism has no influence on LOAD susceptibility, the study may be limited by the size of the sample. In polygenic and multifactorial model of the etiopathology for LOAD, it has been hypothesized that there may be several additive genes each one of them with low weight for the final product (the phenotype). Thus, the chance of detecting these putative genes may be reduced in relatively small samples and negative findings in this case do not mean necessarily lack of association.

We also investigated if there was association between homozygosity and LOAD. There are some reports showing association of homozygosity of other genetic polymorphisms and some neuropsychiatric disorders. This type of association may represent a heterozygosity advantage, probably because the presence of two different molecular forms of the neurotransmitter receptor, resulting in an increased ability to respond adaptively to variations in the environment ${ }^{27}$. However, in our sample there was not found such association as well.

Finally, we also investigated a point mutation in the exon 9 of PAFAH gene, which alter the enzymatic activity $^{19}$. However, in our Brazilian case-control sample this mutation was very rare, thus we consider unlikely that this variant influences the risk to LOAD in our population.

We are aware of other methodological weakness in our investigation. Population stratification is the most common reason for conflict results in genetic studies ${ }^{28,29}$. Investigations comparing different ethnical populations have shown significant variations in the allelic frequency. Power to detect association may be reduced in ethnic admixture samples ${ }^{29}$. In order to face such a problem we can try to identify the ethnical origin of the sample and try to compound homogenous samples. However, in Brazil, physical characteristics such as skin pigmentation, hair colour and texture, shape of the nose and lips, are poor predictors of genomic ancestry ${ }^{30}$. Moreover the fact that the present sample is in Hardy-Weinberg equilibrium may indicate that our sample may not have important problems of population stratification ${ }^{29}$.

In conclusion, in our sample we were able to find an association between LOAD and BanI CPLA2 polymorphism, indicating that this polymorphism may play a role in the susceptibility for LOAD in our Brazilian sample. However more comprehensive polymorphism coverage within the $C P L A 2$ and $P L A 2$ investigated is warranted in larger samples. Investigations in samples with different ethnic background must be carried out as well.

\section{REFERENCES}

1. Lopes MA, Bottino CM. Prevalence of dementia in several regions of the world: analysis of epidemiologic studies from 1994 to 2000. Arq Neuropsiquiatr 2002;60:61-69.

2. Almeida OP, Shimokomaki CM. Apolipoprotein E4 and Alzheimer's disease in São Paulo-Brazil. Arq Neuropsiquiatr 1997;55:1-7.

3. Jacquier M, Arango D, Villareal E, et al. APOE epsilon4 and Alzheimer's disease: positive association in a Colombian clinical series and review of the Latin-American studies. Arq Neuropsiquiatr 2001;59:11-17.

4. Cação Jde C, Souza DR, Tognola WA, Godoy MR, Pinhel MA. Apolipoprotein E polymorphism in first-degree relatives of patients with familial or sporadic Alzheimer's disease. Arq Neuropsiquiatr 2007;65:295-298.

5. Tanzi RE. A genetic dichotomy model for the inheritance of Alzheimer's disease and common age-related disorders. J Clin Invest 1999;104:1175-1179.

6. Fernandez LL, Scheibe RM. Is MTHFR polymorphism a risk factor for Alzheimer's disease like APOE? Arq Neuropsiquiatr 2005;63:1-6.

7. Silva VC, Ramos FJ, Freitas EM, et al. Alzheimer's disease in Brazilian elderly has a relation with homocysteine but not with MTHFR polymorphisms. Arq Neuropsiquiatr 2006;64:941-945.

8. Barbosa NR, Junqueira R, Vallada H, Gattaz WF. Association between Banl genotype and increased phospholipase A2 activity in schizophrenia. Eur Arch Psychiatry Clin Neurosci 2007;257:340-343.

9. Horrobin DF. The membrane phospholipid hypothesis as a biochemical basis for the neurodevelopmental concept of schizophrenia. Schizophr Res 1998;30:193-208.

10. Brown GG, Levine SR, Gorell JM, et al. In vivo 31P NMR profiles of Alzheimer's disease and multiple subcortical infarct dementia. Neurology 1989;39:1423-1427.

11. Skinner ER, Watt C, Besson JAO, Best PV. Lipid composition of different regions of the brain in patients with Alzheimer's disease. Biochem Soc Trans 1989;17:213-214.

12. Gattaz WF, Maras A, Cairns NJ, Levy R, Förstl H. Decresead phospholipase A2 activity in Alzheimer brain. Biol Psychiatry 1995;37:13-17. 
13. Gattaz WF, Cairns NJ, Levy R, Forstl H, Braus DF, Maras A. Decreased phospholipase A2 activity in the brain and in platelets of patients with Alzheimer's disease. Eur Arch Psychiatry Clin Neurosci 1996;246:129-131.

14. Emmerling MR, Moore CJ, Doyle PD, Carroll RT, Davis RE. Phospholipase A2 activation influences the processing and secretion of the amyloid precursor protein. Biochem Biophys Res Commun 1993;197:292-297.

15. Gattaz WF, Forlenza OV, Talib LL, Barbosa NR, Bottino CMC. Platelet phospholipase A2 activity in Alzheimer's disease and mild cognitive impairment. J Neural Transm 2004;111:591-601.

16. Junqueira R, Cordeiro Q, Meira-Lima I, Vallada H. Allelic association analysis of phospholipase A2 genes with schizophrenia. Psychiatric Genetics 2004; 14:157-160.

17. Tay A, Simon JS, Squire J, Hamel K, Jacob, HJ, Skorecki K. Cytosolic phospholipase A2 gene in human and rat: chromosomal localization and polymorphic markers. Genomics 1995;26:138-141.

18. Forsell PKAL, Kennedy BP, Claesson HE. The human calcium-independent phospholipase A2 gene: multiple enzymes with distinct properties from a single gene. Europ J Biochem 1999;262:575-585.

19. Stafforini DM, Satoh K, Atkinson DL, et al. Platelet-activating factor acetylhydrolase dficiency: a missense mutation near the active site of an anti-inflammatory phospholipase. J Clin Invest 1996;97:2784-2791.

20. McKhann G, Drachman D, Folstein M, Katzman R, Price D, Stadlan EM. Clinical diagnosis of Alzheimer's disease: report of the NINCDS-ADRDA Work Group under the auspices of Department of Health and Human Services Task Force on Alzheimer's Disease. Neurology 1984;34:939-944.

21. Peet M, Ramchand CN, Lee J, et al. Association of the Ban I dimorphic site at the human cytosolic phospholipase A2 gene with schizophrenia. Psychiatr Genet 1998;8:191-192.
22. Dawson $\mathrm{E}$, Chen $\mathrm{Y}$, Hunt $\mathrm{S}$, et al. A SNP resource for human chromosome 22 extracting dense clusters of SNPs from the genomic sequence. Genome Res 2001;11:17.

23. Meira-Lima I, Michelon L, Cordeiro Q, Cho HJ, Vallada H. Allelic association analysis of the functional insertion/deletion polymorphism in the promoter region of the serotonin transporter gene in bipolar affective disorder. J Mol Neurosci 2005;27:219-224.

24. Cordeiro Q, Siqueira-Roberto J, Zung S, Vallada H. Association between the DRD2 -141C insertion/deletion polymorphism and schizophrenia. Arq Neuropsiquiatr 2009;67:191-194.

25. Blacker D, Bertram L, Saunders AJ, et al. Results of a high-resolution genome screen of 437 Alzheimer's disease families. Hum Mol Genet 2003;12:23-32.

26. Yu G, Nishimura M, Arawaka S, et al. Nicastrin modulates presenilin-mediated notch/glp-1 signal transduction and betaAPP processing. Nature 2000;407:48-54.

27. Bertola V, Cordeiro Q, Zung S, Miracca EC, Vallada H. Association analysis between the C516T polymorphism in the 5-HT2A receptor gene and schizophrenia. Arq Neuropsiquiatr 2007;65:11-14

28. Silva MA, Cordeiro Q, Miracca EC, Guindalini C, Vallada H. Distribution of alleles of the VNTR polymorphism in the 3'-untranslated region of the DAT1 gene (SLC6A3) in São Paulo/Brazil and its importance to genetic studies of neuropsychiatric disorders in ethically admixed populations. Rev Med Chil 2005;133:1392-1393.

29. Cordeiro Q, Souza BR, Corrêa H, Guindalini C, Hutz MH, Vallada H, RomanoSilva MA. A review of psychiatric genetics research in the Brazilian population. Rev Bras Psiquiatr 2009 (in press).

30. Parra FC, Amado RC, Lambertucci JR, Rocha J, Antunes CM, Pena SD. Color and genomic ancestry in Brazilians. Proc Natl Acad Sci USA 2003;100:177-182. 